Anna K Farmery ${ }^{1}$, Karen A Alexander ${ }^{2,3}$, Kelli Anderson ${ }^{2,3}$, Julia L Blanchard ${ }^{2,3}$, Chris G Carter $^{2,3}$, Karen Evans ${ }^{2,4}$, Mibu Fischer ${ }^{5}$, Aysha Fleming ${ }^{2,6}$, Stewart Frusher ${ }^{2,3}$, Elizabeth A Fulton ${ }^{2,4}$, Bianca Haas ${ }^{2,3}$, Catriona K Macleod ${ }^{2,3}$, Linda Murray ${ }^{7}$, Kirsty L Nash ${ }^{2,3}$, Gretta T Pecl ${ }^{2,3}$, Yannick Rousseau ${ }^{2,3}$, Rowan Trebilco ${ }^{2,4}$, Ingrid E Van Putten ${ }^{2,4}$, Senoveva Mauli $^{1}$, Leo X C Dutra ${ }^{2,5}$, Dean Greeno ${ }^{8}$, Jeremie Kaltavara ${ }^{1}$, Reg Watson ${ }^{2,3}$, and Barbara Nowak $^{2,3}$

${ }^{1}$ Australian National Centre for Ocean Resource and Security, University of Wollongong

${ }^{2}$ Centre for Marine Socioecology, University of Tasmania

${ }^{3}$ Institute for Marine and Antarctic Studies, University of Tasmania

${ }^{4}$ CSIRO Oceans and Atmosphere

${ }^{5}$ CSIRO Oceans and Atmosphere, St Lucia

${ }^{6}$ CSIRO Land and Water

${ }^{7}$ College of Health, Massey University

${ }^{8}$ College of Arts, Law and Education, University of Tasmania

October 20, 2020

\title{
Food for all: designing sustainable and secure future seafood sys- tems
}

Anna K. Farmery*1, 2, Karen A. Alexander ${ }^{2,3}$, Kelli Anderson ${ }^{2,4}$, Julia L. Blanchard ${ }^{2,3}$, Chris. G. Carter ${ }^{2,3}$, Karen Evans ${ }^{2,5}$, Mibu Fischer ${ }^{7}$, Aysha Fleming ${ }^{2,6}$, Stewart Frusher ${ }^{2,3}$, Elizabeth A. Fulton ${ }^{2,5}$, Bianca Haas $^{2,3}$, Catriona K. MacLeod ${ }^{2,3}$, Linda Murray ${ }^{8}$, Kirsty L. Nash ${ }^{2,3}$, Gretta T. Pecl ${ }^{2,3}$, Yannick Rousseau ${ }^{2,3}$, Rowan Trebilco ${ }^{2,5}$, Ingrid E. van Putten ${ }^{2,5}$, Senoveva Mauli ${ }^{1}$, Leo X.C Dutra ${ }^{2,7}$, Dean Greeno ${ }^{9}$, Jeremie Kaltavara $^{1}$, Reg Watson ${ }^{2,3}$ and Barbara Nowak ${ }^{2,4}$

*afarmery@uow.edu.au

${ }^{1}$ Australian National Centre for Ocean Resource and Security, University of Wollongong, Wollongong, New South Wales, Australia

${ }^{2}$ Centre for Marine Socioecology, University of Tasmania, Hobart, Tasmania, Australia

${ }^{3}$ Institute for Marine and Antarctic Studies, University of Tasmania, Hobart, Tasmania, Australia

${ }^{4}$ Institute for Marine and Antarctic Studies, University of Tasmania, Newnham, Tasmania, Australia

${ }^{5}$ CSIRO Oceans and Atmosphere, Hobart Tasmania, Australia

${ }^{6}$ CSIRO Land and Water, Hobart, Tasmania, Australia

${ }^{7}$ CSIRO Oceans and Atmosphere, St Lucia, Queensland, Australia

${ }^{8}$ College of Health, Massey University, Massey, New Zealand

${ }^{9}$ College of Arts, Law and Education, University of Tasmania, Hobart, Tasmania, Australia 
This paper is part of the Future Seas project (www.futureseas2030.org), and has been submitted to the Future Seas special issue in Reviews in Fish Biology 8 Fisheries to be published in 2021

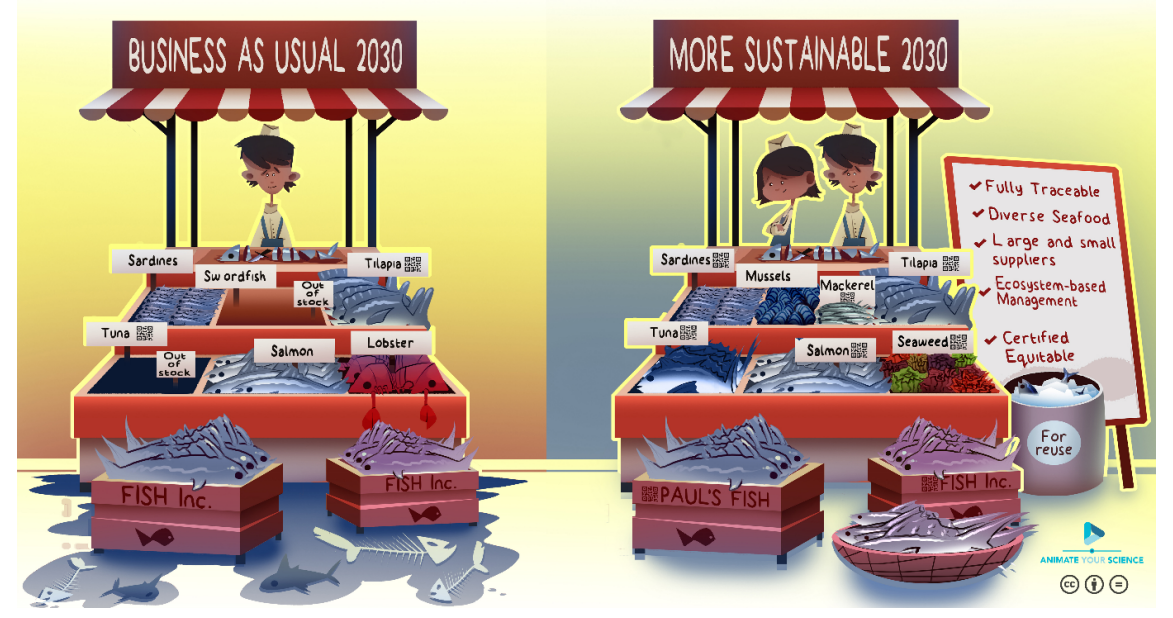

\begin{abstract}
Food from the sea can make a larger contribution to healthy and sustainable diets, and to addressing hunger and malnutrition, through improvements in production, distribution and equitable access to wild harvesting and mariculture resources and products. The supply and consumption of seafood is influenced by 'drivers' including ecosystem change and ocean regulation, the influence of corporations and evolving consumer demand, as well as the growing focus on the importance of seafood for meeting nutritional needs. These changes need to be examined in a holistic way to develop an informed understanding of the needs, potential impacts and solutions that align seafood production and consumption with relevant 2030 Sustainable Development Goals (SDGs). This paper uses an evidence-based narrative approach to examine how the anticipated global trends for seafood might be experienced by people in different social, geographical and economic situations over the next ten years. Key drivers influencing seafood within the global food system are identified and used to construct a future scenario based on our current trajectory (Business-as-usual 2030). Descriptive pathways and actions are then presented for a more sustainable future scenario that strives towards achieving the SDGs as far as technically possible (More sustainable 2030). Prioritising actions that not only sustainably produce more seafood, but consider aspects of access and utilisation for all, particularly those who are food and nutrition insecure, is an essential part of designing sustainable and secure future seafood systems.
\end{abstract}

\title{
Key words
}

Food and nutrition security; equity; mariculture; wild capture fisheries; blue food; food system

\section{Introduction}

Food from the sea has been crucial for human survival for over 150,000 years (Marean et al. 2007) and has helped to shape human evolution (Crawford and Broadhurst 2012). Seafood plays a particularly important role in food and nutrition security through its high concentrations of bioavailable minerals and vitamins, essential fatty acids and animal protein (Hicks et al. 2019; Thilsted et al. 2016). For many countries, including some Small Island Developing States, seafood contributes, or exceeds, $50 \%$ of total animal protein intake (FAO 2018). Seafood is also vital for the almost 30 million coastal Indigenous Peoples who consume nearly four times more seafood per capita than the global average, and 15 times more per capita than nonindigenous peoples in their respective countries (Cisneros-Montemayor et al. 2016). However, terrestrial- 
bias remains evident in debates on food and nutrition security (Béné et al. 2015) and on mechanisms to end hunger (see for example Nature 2020). Promotion of seafood as an important component of a healthy and sustainable diet (Bennett et al. 2018; Bogard et al. 2019a; Farmery et al. 2017; HLPE 2014b), due to its nutritional profile and comparatively favourable environmental footprint (Hoegh-Guldberg et al. 2019; IPCC 2019; Willett et al. 2019), is helping to overcome this bias. Food from the sea can make an important contribution to improved food outcomes, however, it will require careful management of marine and terrestrial resource use in combination with efforts to ensure efficient and equitable distribution of resources, products and benefits (Österblom et al. 2020). Conversely, reducing the supply of seafood will potentially contribute to malnutrition and hunger, as well as lead to potentially negative environmental impacts related to replacing seafood with food produced on land (Barange 2019; Golden et al. 2016).

Seafood, defined here as any edible form of marine life (plant, animal, bacteria), that requires sea water for at least part of its life cycle, is predominantly sourced through the wild harvest of a broad range of plants and animals. Approximately half of 79.3 million tonnes of wild harvest seafood landed in 2016 (FAO 2018) was from small-scale fisheries (SSF), which typically operate close to shore with relatively simple gear and catch fish for subsistence or local markets. SSF are fished by a diverse group of men and women and are embedded in local economies, traditions and values (FAO 2015). They are particularly important for livelihoods and income generation, supporting $88 \%$ of fish workers globally (FAO 2018). It is estimated that production of food from the sea can increase substantially (Costello et al. 2020; Cottier-Cook et al. 2016; Gentry et al. 2017; Schubel and Thompson 2019; World Bank 2013) through a combination of improved management of wild harvesting and increased growth of mariculture. We define mariculture as the cultivation of marine plants and animals for food and other products in the open ocean, enclosed sections of the ocean and bays, or in tanks, ponds or raceways containing seawater. However, mariculture systems have not accelerated at the same pace as freshwater aquaculture (Tacon et al. 2011) with 28.7 million tonnes of fish and invertebrates and a further 30 million tonnes of seaweed produced in 2016. This production represents less than half of total global animal aquaculture production. In addition, while increased production will raise the global availability of seafood, it does not automatically lead to improved food outcomes, particularly for food insecure people with limited access to seafood resources (Belton et al. 2020; FAO 2009).

The way in which seafood is produced, distributed and consumed is changing rapidly with ecosystem change and ocean regulation, the influence of corporations and evolving consumer demand, as well as the growing focus on the importance of seafood for meeting nutritional needs. Optimising the role of the ocean in sustainably feeding the world's population has been identified as one of the key challenges for the United Nations 'Decade of Ocean Science for Sustainable Development' 2021 - 2030. Meeting this challenge in the coming decade, for a projected 8.6 billion people with varied physical and financial access to seafood, cultural food practices, and food preferences, will require coherent, integrated and flexible solutions that consider the inter-sectoral and cross-national nature of food systems (Bai et al. 2016; Sachs et al. 2019). It will also need to consider the range of trade-offs between food production and other uses of marine space and resources (Cohen et al. 2019; Farmery et al. in review).

Taking a food system approach, which considers the way in which food is produced, processed, delivered and consumed, as well as how these elements intersect with human health, the environment, economics and society (HLPE 2014a; Imagine a world 2020), is important given the historical lack of attention to the ways different people will gain, lose, or be excluded from access to fish resources, or to fish as a food commodity (Belton et al. 2020; HLPE 2014b; Tezzo et al. 2020). This paper examines the anticipated global trends for seafood systems, or seafood within the broader food system (based on our definition of seafood), over the next ten years and identifies key pathways that could shift the current trajectory to a more sustainable 2030, consistent with the UN's Sustainable Development Goals, predominantly SDG2 (Zero hunger), SDG3 (Good health and wellbeing), SDG12 (responsible consumption and production) and SDG14 (Life below water).

This paper aims to support the alignment of seafood production and consumption with goals to transform food systems toward healthy diets that both nurture human health and support environmental sustainability (Willett et al. 2019). We firstly identify and describe key 'drivers' that influence seafood now and will 
continue to do so over the next decade. We use these drivers to construct a future scenario based on current trajectories reported in the literature (Business-as-usual 2030). We then present a more sustainable future scenario that strives towards achieving the SDGs as far as technically possible (More sustainable 2030) and descriptive pathways and actions that can be undertaken to achieve this more sustainable future. The two future scenarios are described through three fictional, yet evidence-based, narratives, to demonstrate how the anticipated futures might be experienced by people in different social, geographical and economic situations.

\section{Methods}

This study forms part of the Future Seas project (www.FutureSeas2030.org) which aims to improve society's capacity to purposefully shape the direction of marine social-ecological systems over the course of the UN Decade of Ocean Science for Sustainable Development. The interdisciplinary project involved a three-stage process to explore alternate futures for the world's oceans in relation to a range of pressing global challenges. Food and nutrition security was identified as one of 12 important challenges facing the oceans and our society during the first stage of the project. More information on this stage and the other challenges identified is available in Nash et al. (in review-b). The second stage of the project, future discovery and development, involved creating the future scenarios for each of the 12 challenges identified. The scenarios were developed based on the perspectives and expertise of groups of cross-disciplinary researchers using an iterative approach (see Nash et al. in review-b this issue for full method). For the challenge that this paper details (sustainable and secure seafood systems), this approach involved identifying the main drivers shaping food and nutrition outcomes from seafood, both now and in the near future, followed by forecasting two alternative 10-year futures based on these drivers: a 'Food for some' scenario which maintained a 'Business-as-usual' trajectory from 2020 and reflected current inequalities in access to seafood; and a 'Food for all' scenario reflecting a more optimistic, sustainable, and equitable 2030 that incorporates activities to move beyond 'Business-asusual' and make seafood more available and accessible for all people. Key pathways and actions to achieve the sustainable 2030 future were then identified and a backcasting exercise was undertaken to check the actions identified were sufficient for realistically achieving a sustainable 2030 (Figure 1). The final step of the project focussed on learning across all the 12 challenges and is discussed further in Nash et al. (in review-b).

We acknowledge that the unprecedented disruptions of 2020, in particular the COVID-19 pandemic, are causing major changes to economies and socioecological systems at the global scale. The Business-as-usual scenario we describe is based on evidence from the recent past before the pandemic, and assumes a general return to this trajectory in the next few years. We note that current disruptions to the global ocean, environment and society because of COVID-19 may present a platform for change and an opportunity to 'reset' trajectories in the coming decade (see Pecl et al. (in review), this issue). The sustainable future presented here is one option for such a shift, and should not be viewed as an end goal, but as a research tool to stimulate further investigation and discussion (Evans et al. 2013). 


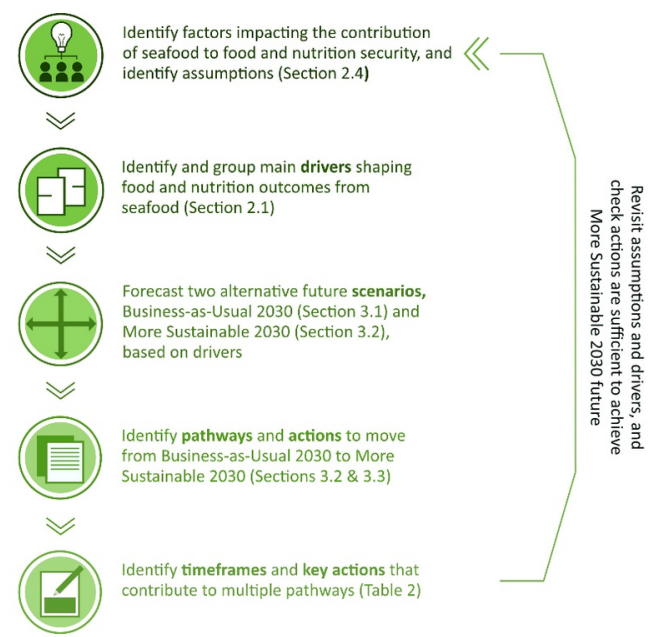

Figure 1 Steps involved in the identification of drivers and development of scenarios and pathways.

\section{Identifying key drivers}

Factors that have the potential to influence the production, distribution and consumption of food from the sea over the next decade were identified by the co-authors and grouped into six overarching drivers based on their main characteristics (see Table S1): ecosystem change; ocean governance; influence of corporations; output and efficiency of seafood systems; consumer demand; and focus on nutrition. These six drivers and a summary of their main characteristics (Table 1) based on the literature and expert opinion of co-authors were used to inform the future scenarios and to describe how they might influence future seafood systems (see supplementary information for further detail on drivers and references).

Table 1. Drivers of seafood systems, summary of their key characteristics and implications for sustainability and food security (see supplementary information for more details and references).

\section{Ecosystem change Key characteristic}

Change in biomass and redistribution of many species

Increasing intensity and frequency of extreme weather events

Pollution and warming of coastal waters

Redistribution of disease vectors and pathogens

Ocean governance

Fishery management operating at national and sub-national scales, multiple agencies tasked

Fisheries subsidies entrenched and fishing fleets continue to grow in many countries

Divestment in fisheries sustainability programs

Growing presence of resource-based activities in the ocean, propelled by a blue economy

Fisheries management focus on economic and ecosystem benefits and does not recognise the Development of alternative regional and subregional multilateral agreements, including Indis

Influence of corporations Ongoing consolidation and concentration of company ownership along supply chains

Independent certification schemes and corporate initiatives are helping to improve transpare

Increased fish consumption through growth of transnational retail chains and supermarkets

Loss of food and livelihoods for small scale operators and conflicts around access rights and Several corporations are engaged in programs and platforms to improve sustainability along 


\begin{tabular}{|c|c|}
\hline Ecosystem change & Key characteristic \\
\hline Output and efficiency & $\begin{array}{l}\text { Substantial innovation and improvements in feed conversions ratios in animal mariculture } \\
\text { Global mariculture production is limited to a narrow range of species, typically farmed unde } \\
\text { The majority of mariculture species have been cultured for a relatively small number of gen } \\
\text { Decreased wastage on boats } \\
\text { Technological improvements can benefit fisheries economics and sustainability (e.g. fuel use } \\
\text { Post-harvest losses, including quality loss and discarding, are common }\end{array}$ \\
\hline Consumer demand & $\begin{array}{l}\text { Seafood consumption in many low-income countries is driven by local supply, wealthier cons } \\
\text { Consumers are generally motivated by taste, price and convenience, rather than sustainabili } \\
\text { 'Sustainability' labelling systems have influenced behaviour in high-income countries }\end{array}$ \\
\hline Nutrition focus & $\begin{array}{l}\text { Seafood products are the only source of key macro and micronutrients for some people, prec } \\
\text { Increased demand for omega- } 3 \text { fatty acids, primarily sourced through marine ecosystems an } \\
\text { Growing appreciation of how a 'planetary health' perspective can achieve environmental and }\end{array}$ \\
\hline
\end{tabular}

\section{Business-as-usual 2030 scenario - Food for some}

Based on the key characteristics of the six drivers identified, we identified 84 unique evidence-based outcomes anticipated to occur in the next decade (Table S1) under a Business-as-usual scenario. These anticipated outcomes were then used by the co-authors to frame three narratives based on co-authors perspectives and expertise, and grounded in the literature, to present the scenario. The three narratives were created to reflect the varied ways in which the future, under current ongoing trajectories, might be experienced by different people. This reflection included rural and natural resource-based communities that are often overlooked in mainstream conceptualisations of sustainable development (Lowery et al. 2020). The use of narratives allowed the co-authors to explore and envisage how the drivers might shape the future in 2030 in different contexts, without being overwhelmed by dystopian visions of irreversible environmental degradation and societal collapse that have tended to dominate other future scenario work (Bennett et al. 2016; RaudseppHearne et al. 2019). This narrative approach has previously been shown to be a valuable communication technique for comparing and evaluating science policy contexts (Dahlstrom and Ho 2012; Merrie et al. 2018; Olson 2015). However, we recognise that this approach is limited by the lived and academic experience of the author group and that not all aspects of future food and nutrition security can be represented in one narrative, or in one research paper.

\section{More sustainable 2030 scenario, pathways and actions - Food for all}

A 'More sustainable 2030' scenario was developed to address the limitations to seafood contributing to food and nutrition security raised through the Business-as-usual scenario, and move beyond this anticipated future. The alternative 2030 is intended to be consistent with the EAT-Lancet strategies for transforming food systems to be more sustainable and equitable (Willett et al. 2019) as well as the objectives outlined in the Sustainable Development Goals (SDGs) (United Nations 2015), in particular those classified as integral (SDGs 2, 3, 12 and 14) and closely associated (SDGs 1, 5, 8, 10,13,15, 16 \& 17) to food and nutrition security and seafood (Table S2). While we note that all SDGs and targets can be linked to food and nutrition security and oceans (Blanchard et al. 2017; Hambrey 2017; Rockström and Sukhdev 2019; Singh et al. 2018), some are arguably more closely associated than others (e.g. Nippon Foundation 2017), and that these can be identified to help target key actions to deliver change. The identification of key relevant SDGs, involved a qualitative classification of all SDGs as either integral, closely associated, or peripherally linked to the challenge identified. This process occurred via internal group discussion and consensus by all co-authors. To develop the scenario, the authors identified five areas or pathways for change and actions to underpin the pathways and move away from 'Business-as-usual' towards the 'More sustainable' future. The pathways and actions were developed based on authors' expertise and knowledge of existing research and case studies. The 
actions were refined to account for overlap, where the same action appeared under multiple drivers, resulting in 23 key actions (Table S3). The summarised actions were then linked with pathways to demonstrate a way forward. The process of developing the scenario, pathways and actions, was iterative and aimed to identify the 'More Sustainable' futures that were technically feasible and capable of being accomplished over the time period 2021-2030.

\section{Assumptions}

The identification and description of drivers, actions and pathways was based on several overarching assumptions. Cross-challenge assumptions identified were general in nature and related to: (1) events that could not reasonably be anticipated within the scope of the Future Seas Key Challenges, (e.g. global-scale conflicts), (2) well-known dynamics for which we could assume current predictions would hold over the next ten years (e.g. climate change), (3) factors that are unlikely to change over the course of the Decade of Ocean Science (e.g. cessation of all fishing) (see Nash et al. in review-b this issue). Additional, challenge-specific assumptions relevant to seafood systems are available in the supplementary information. We acknowledge that our pathways and actions represent possible ways toward achieving sustainable and secure seafood systems for all in association with relevant SDGs, however, they are not the only pathways and actions that could be implemented.

\section{Results and Discussion - Imagining the future}

In this, and the following section, we outline possible future scenarios for seafood systems and food and nutrition security. We begin with the Business-as-usual 2030 scenario (section 3.1), presented from the perspective of three fictional characters. We then describe a more sustainable 2030 (section 3.2) which is conceptualised through five main pathways for change (Section 4).

\section{Scenario 1 - Food for some (Business-as-usual 2030)}

The narratives used to present the Business-as-usual scenario are intended to provide a snapshot into the lives of three fictional characters in the year 2030 as we anticipate it to be based on current evidence (see Table S1). The aim of these fictional narratives is to translate the vast amount of information available in the literature relating to our drivers, and their potential influence on seafood systems in the next decade, into more accessible personal accounts. It is hoped these personal accounts 'bring-to-life' the key characteristics of the drivers (Table 1 and S1) and enable the reader to actually imagine how 2030 may be experienced by different people. The characters identified have been deliberately left vague and simplistic in their behaviour. Citizen 1 represents a middle-class diner in a developed economy who is concerned about food sustainability and nutrition, and motivated by price. Citizen 2 represents a mariculture enterprise employee in Asia, where mariculture is currently projected to increase on a large-scale. Citizen 3 represents an elder living in a Small Island Developing State who has witnessed large changes in fishery resources.

Citizen 1 - Finn, 'wellbeing' advisor

What a busy week. My partner and I are treating ourselves to dinner out tonight. We order salmon. A steak would be good for our iron levels, but it is too expensive these days with the red meat tax. Also, fish is more sustainable than red meat and it is definitely more nutritious than the ready-to-eat fake-meat curries we've been having during the week, or the 3D printed fish nuggets they sell at the canteen. I scan the code on the menu and see that my fish is imported and farmed. Wild fish have been really expensive lately, maybe because there have been problems with disease outbreaks. I don't touch seafood without a code these days, which makes a lot of products off-limits as they don't have any information on where they come from and how they were produced. My fish isn't local, which I would prefer as I think local is more sustainable and better quality, but it is still very fresh as it was harvested yesterday and flown directly here. I can see the drones out the window flying between the restaurant district and the airport, carrying fish and other fresh goods. I would like to catch my own fish, you can't get better quality than that, but I don't really know 
what the local fish are anymore. The species seem to have changed quite a lot in the last few years. We used to catch cod off the local pier, but it washed away last month, and with bad storms coming frequently now, there doesn't seem to be a plan to rebuild. I check the code again for some ethical information and the details on what the fish was fed, but nothing is listed. I worry about all the microplastics in food, but the code shows that this fish has a low microplastic-content score which is good, probably from all the insects that go into animal feeds these days. I sync the salmon's provenance data with my nutrition app and see the orange tick for my daily intake. Next time I'll pre-order an off-shore farmed fish, fed with marine algae. It's more expensive but it has great nutritional value. At least my fish is fresh and will be grilled. And we can add some anchovy powder on top to get the green tick for meeting my daily micronutrient requirements. Once I get the tick I think I'll celebrate with a glass of wine.

Citizen $2-\mathrm{Li}$, mariculture enterprise manager

The company has reached a milestone! We can grow our fish to market size in half the time it took in 2020. We are now a very high tech and large-scale operation with genetic improvement and feed formulations matched to specific fish requirements. Our management operations, vaccines and forecasting tools are also targeted to prevent disease. Currently we are only focused on the high value grouper species as we couldn't access or afford to implement the same level of knowledge for lower value species, or overcome complex environmental problems to make Integrated Multi-Trophic Aquaculture (IMTA) work for us. But the upside is that due to our success with grouper, we are now looking to farm other high value species, including some of the most challenging such as giant tuna. Our company is well ahead of many of our competitors and the small-scale operators who have not updated their production systems for many years. I remember when I first started we used to farm these fish on the coast, but most of our production is now either land-based, with recirculating systems, or off-shore. The pollution and extreme weather impacts on coastal farming mean it is just too expensive to farm there anymore, not to mention the difficulty to get permits or support from community groups. The company owns all the fish and the crop farms in the region, as well as the processors and feed mills. It means we can assess our efficiency along the whole supply now. We do still lose some fish, but technology and traceability makes it easier to get all the certifications and sell internationally. That's important in some markets these days, especially some international markets where we can get a good price. There's a lot of demand from the bigger cities, especially for higher value products, so we are doing well. We are making a lot of ready-to-eat meals. Not my favourite, but it's what customers want. We are also servicing new markets in the smaller towns. New processing and packaging have really improved shelf life and the quality of products. Given it's a high value product, our prices are very competitive, and so the company has become very well known. I think they are a great employer, but it is hard for smaller operators who are struggling to source feed and keep their prices low. I hear it is just as hard, or harder, for the wild fishers. Lots of them are getting out of the industry as there are no jobs unless you work for a big company. It does upset me to see the change in the coastal towns. As people have moved out of the fishing industry, the coastal communities are not what they once were. I used to enjoy the local fishing festival, but there are not enough fishers to run it any more. Still... the way the company does things is very efficient and production continues to increase. Perhaps we should start a new festival, a festival of mariculture.

Citizen 3 - Kei, village chief and retired fisher

We are all in the main building tonight. The last storm destroyed many houses. As terrible as the storm was, it was a joy to have the community together again to cook. We don't all come together every night to eat like we used to. A lot of our food these days is packaged imported food, so we tend to eat on our own. Not like the old days when we'd all sit together and share the big fish we'd just caught, and everyone would bring along vegetables and crops to share - all caught, grown and prepared using traditional methods passed down through generations. Catching our own fish on the coast has become difficult. The reefs around here are not healthy, they have suffered from bad fishing practices, bleaching, pollution or sedimentation from runoff. The rising sea levels and storms haven't helped, neither have the new developments they keep putting in. The fish just don't seem to be around as much anymore, and the ocean has changed. The market vendors are saying the same thing. They can't seem to get their hands on fresh local fish at the moment. They say it's 
around, but a lot is exported or is bought by resorts for the tourists, especially the deep-bottom snappers and other species that don't cause ciguatera poisoning. Other countries pay to catch the fish further off-shore, but there's been a lot of fighting recently. The fish have been moving and our borders are being crossed by new boats ready to take what they can. In the past the government wasn't focussed on what was happening to the fisheries on the coast. Now they see we need better coastal monitoring and management, and more support for the domestic sector to adapt to all the changes. They tried to help traders get fish to markets quicker, for better fish safety and quality, and they tried to work with other countries to set up mariculture here. But it seems the ocean has changed too fast and we are all racing to keep up now. The subsistence fishers have really struggled. I hope it's not too late to turn things around and get our wild fish back on the coast.

\section{Scenario 2 - Food for all (More sustainable 2030) pathways and actions}

The more sustainable 'Food for all' scenario described below, together with the pathways for change, were developed to move beyond the 'Business-as-usual' scenario by addressing the factors limiting the contribution of seafood to food and nutrition security outlined in Table 1 and S1. This vision for a more sustainable 2030 is described through five key pathways of actions, in addition to effective governance, aimed at facilitating seafood for all. The Food for all scenario is illustrated through narratives, which have been linked back to the characters from the Business-as-usual scenario and to the five pathways.

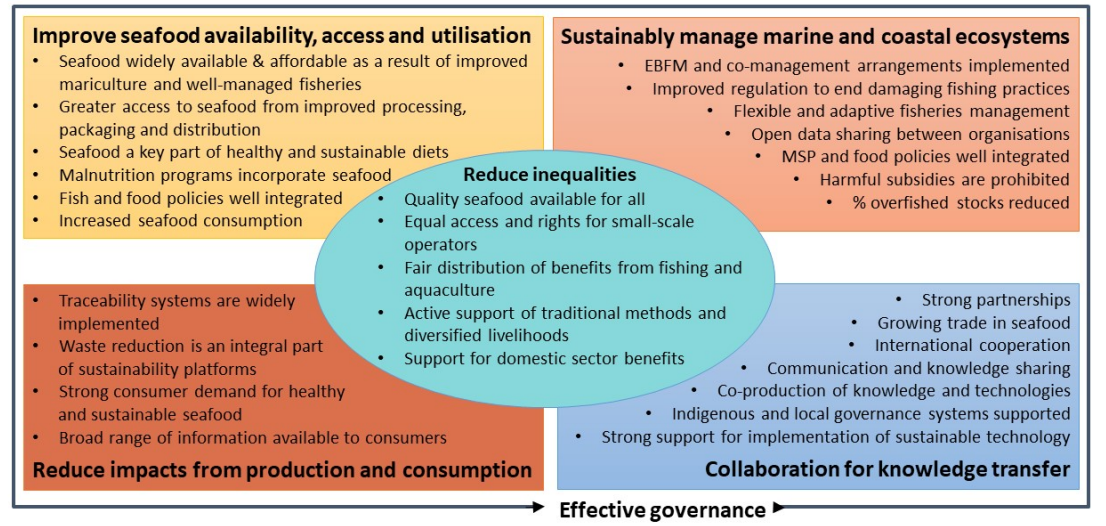

Figure 2 Vision of a More sustainable 2030 including key pathways for change and their characteristics (see Table S3 and Figure S1 for more details)

Pathway 1 - Improve seafood availability, access and utilisation

Seafood production and consumption in 2030 has increased as a result of adaptive and flexible fisheries management, increased mariculture production and the global shift towards healthy and sustainable diets. In contrast to the Food for some scenario (Business-as-usual 2030), the increased consumption of seafood, and contribution to addressing nutritional needs, is measurable at both national and local levels (Taylor et al. 2019), particularly in those areas most dependent on seafood resources. The importance of maintaining wild capture fisheries as a food resource has been widely recognised (Allison 2011). A broad range of seafood produced through wild capture and mariculture is widely available and affordable as a result of improvements and innovations in production and management as well as prioritisation of access and utilisation along supply chains (Butcher et al. 2020; FAO 2020b; Swanepoel et al. 2020; Swedbio and ACIAR 2020; Thilsted et al. 2016) (Box 1). These improvements have been driven by a shift in policy focus toward nutrition security as well as in response to major supply disruptions, such as the 2020 COVID-19 pandemic (FAO 2020a; Farrell 
et al. 2020). Productivity has increased where this was intended, however, in other systems there has been a focus on support for local activities which enhance direct and fair distribution based on the existing level of production, rather than focusing on producing more fish. In these systems, social and cultural values of local food have been prioritised over production efficiencies through private and public sector efforts (Johnson et al. 2018).

Supply chain technology and innovation has also reduced and redirected waste and improved seafood quality. Innovative processing methods resulting in new secondary products have seen fish products reach destinations where they previously could not (Gokoglu 2019). Companies and governments have worked together to ensure fish remains affordable (Belton et al. 2020) and there is increased data availability to ensure that processed seafood products are nutritious and free from contaminants (Moxness Reksten et al. 2020). Seafood is a ubiquitous ingredient in malnutrition programs and school feeding programs and fishery and food policies are now well integrated. Food from the sea continues to contribute to poverty eradication and provide meaningful work for millions of small-scale fishers and farmers (FAO 2015).

Citizen 3 - Kei, village chief and retired fisher

The subsistence fishers have really struggled, but it's not too late to turn things around. Many fishers are now involved in the edible seaweed industry. We have developed sustainable seaweed food chains which provide reliable access to fresh food as well as incomes. There are many native seaweeds that are high in fibre and micronutrients such as iodine, zinc and magnesium. People ate seaweed a long time ago, and we have worked hard to restore and understand traditional use and knowledge of these seaweeds. Women's organisations across the region are involved in seaweed wild harvest and nutrition and cookery programs. The women also had the idea to make fish-based powder, using fish, salt and other ingredients bought locally. The fish powder extends the shelf life of fish and can be added to rice porridge. It tastes good and provides important nutrients, particularly for our youngest children. The fish powder is used at home but also in feeding programs at primary schools and in hospitals.

Pathway 2 - Sustainably manage marine and coastal ecosystems

The number of fisheries considered overfished has reduced since 2020 as a result of greater collaboration and data sharing between management organisations, improved monitoring of national fleets, greater government and industry commitment to sustainability and improved capacity in the development and implementation of fisheries management frameworks (Hilborn et al. 2020). Major fleets now have e-monitoring systems widely implemented allowing for real time monitoring and documentation of catches (Mangi et al. 2015). Fishery management has become flexible and adaptive to deal with changing oceans (Costello et al. 2016; Dutra et al. 2019; Gaines et al. 2018; Mahon and Fanning 2019; Rudolph et al. 2020). There has also been a strong focus on establishing, or transitioning, national fisheries management into sustainable and adaptive frameworks focused on maintaining ecosystem structure and function, as well as recognising cultural values with a broader outcome that balances enhancing productivity with ensuring equity in access to resources (Allison et al. 2020). Management plans allow coordination across gear-based or polyvalent fleets to achieve a balanced harvest in high-income countries, and new co-management arrangements have been introduced in low-income countries (Eriksson et al. 2016; Zhou et al. 2010). Beneficial subsidies remain but there has been firm global action to prohibit subsidies that contribute to overfishing or that are linked to illegal, unreported or unregulated fishing (Young 2017), including enshrining these principles in World Trade Organisation decisions and other international agreements. Integrating planning, regulatory frameworks, marine resource allocation and food policies has helped to ensure sustainable seafood production, which in turn has provided a strong and equitable economic basis for development in local communities (Sale et al. 2014). Damaging fishing and mariculture practices have been eliminated as a result of increased regulation, enforcement, education and traceability. Increased transparency has translated to improvements in corporate responsibility and accountability, including clear goals and structures in place to ensure implementation (Packer et al. 2019).

Fishers' capacity to dynamically tailor their behaviour to align with ecosystem objectives has increased as a 
result of greater awareness of ecosystem-based and integrated management objectives, social expectations and export market requirements (Smith et al. 2017). Small Island Developing States and low-income countries have benefited from improved management of fisheries, mariculture and tourism. This benefit has occurred primarily through a combination of investment in capability development, implementation of management frameworks and policies and revision of fleets, and corporate incentives aimed at developing stronger public private partnerships with developing countries (Weirowski and Hall 2008). The number of Traditional and Indigenous managed fisheries accessing markets has increased (Cohen and Foale 2013) (Box 2), improving both production of seafood and ecosystem biodiversity in these regions and empowering communities in decision making processes that support long-term sustainability (Borrini-Feyerabend and Campese 2017; IPBES 2019).

Citizen 3 - Chief Kei, village chief and retired fisher

Our marine resources are now managed to create sustainable fisheries through our traditional management systems, which have been combined with modern approaches within Locally Managed Marine Areas (LMMA). Our village uses a spatial and temporal tabu (no-take) system. I have worked with the community to set up tabu areas for the next few years and we expect to be rewarded for our commitment to conserving our fisheries resources through a feast once the tabu is transferred to another area. Tonight, we are bringing everyone in the village together to celebrate the end of a tabu of one of the reefs, we even caught some big snapper that I have been eyeing off over the last few months.

\section{Pathway 3 - Reduced impacts from production and consumption}

Mariculture production has become more sustainable, through increased production of highly nutritious, high quality products over shorter timeframes, and a reduced environmental impact, through improved feed inputs and farming practices (Gephart et al. 2020; Stentiford et al. 2020). Efficiencies in mariculture have improved through intensifying strategic research and identification of more efficient culture species. The increased availability and variety of sustainable mari-feed (aquaculture feed specifically for mariculture) sources, for example from farmed insects and microalgae, has ended conflicts between mariculture and terrestrial production systems (Hua et al. 2019) without increasing pressure on wild capture fisheries as feed sources. A variety of commercially viable production systems, including IMTA (Buck et al. 2018), are operational, improving the quality of the products through filtering by bivalves and macroalgae around the pens (Chen et al. 2017) (Box 3). Work is ongoing to minimise production impacts and further expand sustainable production, including research into understanding the ecological consequences of using mariculture technology to restore heavily overfished stocks (Taylor et al. 2017).

Greater recognition of links between wild capture fisheries and mariculture have resulted in improved management of diseases and parasites (Godwin et al. 2020; Hayward et al. 2011). Seafood waste and loss of quality and nutritional value have been markedly reduced as a result of both improved fishing practices and consumer education (Bogard et al. 2019b). There is a more diverse range of species available on the market and a more stable supply of seafood products as a result of improved fisheries management and the more effective use of species that might have been underutilised or discarded in the past (van Putten et al. 2019). Management improvements have included enhanced access to marine forecasting and operational technologies that support flexibility in targeting, better gear-selectivity on boats, and greater utilisation of catch (including materials once considered waste, such as frames). Fishing pressure is applied across more of the system, although more lightly than in the past, meaning both production and sustainability have benefited. Supply chain technology has improved transport times to consumers and supply chain management and technology has improved, including improved shelf-life of products where cold chains do not function efficiently (Global Panel 2020; HLPE 2014a). Waste has been reduced through education of consumers to eat a broader range of products and waste less through more appropriate purchasing and portion size (Papargyropoulou et al. 2014). This broad-scale change in consumer demand has created feedbacks with a wider range of species and products including marine algae and bacteria, and a broader range of lower trophic level species now considered edible and acceptable as both human food and mariculture feeds. 
Technology is readily available to link consumers with buyers through connected supply chains and consumers have broader access to sustainability information for products from increased traceability. Consumer pressure on companies has helped to transform food production, distribution, processing and consumption to be more environmentally and socially sustainable, with the incorporation of waste reduction into sustainability platforms of large corporations and certification groups. Established corporate programs, such as WaSeaBi (waseabi.eu) and SeaBOS (seabos.org) have been expanded and investment guidelines are now developed with stricter requirements for reinvestment that considers nutrition and sustainability issues in line with the SDGs.

\section{Citizen 2- Li, mariculture enterprise manager}

The company has reached a milestone! We can now grow a range of different species through our improved knowledge of Integrated Multi Trophic Aquaculture (IMTA). The latest guidelines for IMTA have really helped us identify which species to grow together, and how best to work with our commercial partners to optimise both production and environmental benefits, not to mention the skills sharing and workforce stability benefits. This has made the regions where IMTA is practised much better places to live and work and to get stable year round jobs. Our polyculture of shrimp and bivalve filter feeders, like oysters and clams, reduces the discharge of suspended organic matter and other pollutants from our shrimp culture ponds. We have overcome the problems associated with efficiency, high space requirements and bivalve deaths from the high concentration of nitrogen from nitrite and ammonia. The company is also now diversifying and investing in waste management to develop nutritional ingredients from previously waste products. A large amount of our products were ending up in side-streams, mostly used for low-value animal feed or disposed of, which was costly for us. Along with our animals, we now also produce high protein-based food ingredients, aromatic ingredients and mineral supplements for food and feed.

\section{Pathway 4 - Collaboration for knowledge transfer}

Co-production of knowledge on seafood sustainability and adaptation between traditional fishers, scientists and fisheries managers has resulted in wide-scale implementation of new technology, as well as the uptake of traditional management approaches (Norström et al. 2020). Co-production of environmentally sound knowledge and technologies has reduced inequalities in capability and improved the sustainability and productivity of fisheries and mariculture (Österblom et al. 2017; Stoll et al. 2019). There has been targeted engagement by managers, fishers and coastal communities around strategies for responding and adapting to change. Adaptive management frameworks have been implemented with a focus on strategic planning across sectors, and multisector approaches to ocean management that take into account the needs and trade-offs of a broad range of potential users across productive areas as well as sustainability of the environment (Allison et al. 2020).

National institutions have been strengthened through international cooperation, and capacity building has occurred at all levels. The ability of governments to make and implement coherent policies that account for social, economic and environmental goals has been enhanced through the building of pathways that facilitate a two-way exchange of information between society, science and policy makers (Posner and Cvitanovic 2019). Agreements have been established between small and large enterprises to make relevant information for decision making broadly available. Participation of indigenous peoples in planning, management and policy making has been supported (see for e.g. CAUL 2015), allowing for the inclusion of traditional knowledge and methods into new operational, feed and nutrition technologies (Groesbeck et al. 2014; Jackley et al. 2016; Neudorf et al. 2017) and diversification of management frameworks to recognise cultural values and approaches (Box 4). Associated research and developments have led to improvements in efficiency, environmental sustainability and human health benefits of mariculture systems (Stentiford et al. 2020). Increased sharing across researchers, industry, government and international organisations has increased transparency and equity across industries, providing for increased widespread understanding and associated support within broader society.

Citizen 4 -Chia-Ling, traditional mariculturist, daughter-in-law of Li, mariculture enterprise manager 
For thousands of years my family has been gardening the foreshore of our beaches for clams. The knowledge that we use today is a mix between traditional knowledge passed down through many generations and information from modern science. Our clam gardens provide us with important subsistence foods and cultural links between our youth and ancestors, and also allows us to contribute to the economy. The impact that our gardens have on the natural landscapes increases their productivity by $150-300 \%$, which means we have a stable access to market, and we also sell other species like octopus, that now occur in the garden areas due to the increased habitat area. The Indigenous Peoples were certainly engineers and marine resource managers. We are happy to see many opportunities emerging to build on their knowledge to improve the food and nutrition security and livelihoods of Indigenous Peoples and the wider community.

Pathway 5 - Reduce inequalities

Since 2020, management frameworks at national and regional scales, have shifted to provide for equity of access for all stakeholders and are now integrated to incorporate all marine users (Allison et al. 2020). This includes access to productive fishing areas (Cohen et al. 2019), or areas suitable for mariculture, and processes that provide for real-time monitoring of access rights. More corporations prioritise ethical investment strategies and production practices and this change in priority is evident through improved reporting and transparency, and stricter requirements for investment guidelines (Porter and Kramer 2019). Governments and companies are working through partnerships to provide support for the engagement of small-scale fishers and farmers. Business opportunities and access rights for traditional owners have been created to ensure their participation in fisheries and mariculture (Hiriart-Bertrand et al. 2020). There are a range of diverse approaches to sustainability that are more suited to small-scale fisheries or those in developing nations, than previous certification systems, leading to more localised and sustainable production systems (Stoll et al. 2019). Women are fully engaged in decision-making around seafood and their role in seafood and food security is recognised (Alonso-Poblacion and Siar 2018; Eriksson et al. 2018) (Box 5).

In countries receiving benefits from off-shore licenses there has been a shift toward greater capacity to monitor the catches and more flexible schemes that provide for setting dynamic access levels depending on the productivity within national boundaries, resulting in more sustainable fishing (Bell et al. 2015). There has also been a shift in government policy from focussing on export markets, which limited wealth generation to some parts of the seafood chain, to supporting domestic sector benefits. Some countries have opted to fish their own resources and have established effective management systems, including secure catch share models. Regulatory and market-driven improvements in domestic, low-value, seafood chains has improved food quality and safety (McClean et al. 2019). The benefits of fishing and mariculture are distributed more equally between and within nations and regions, as a result of better partnerships with corporations and strengthened governance to ensure equal distribution of benefits (Osterblom et al. 2020).

Citizen 1 - Finn, 'wellbeing' teacher

I check the Q-code again for some ethical information and find that my fish was produced by a company that has 'equitable mariculture' certification. The company is committed to equitable sharing of benefits across different stakeholder groups, both direct and indirect beneficiaries. The company also supports women's entrepreneurial activity and engages them in higher value nodes in fish value chains. The company has partnered with government and NGOs to help set up women fisherfolk organisations that have increased women's participation and leadership in collective action in sustainable fisheries.

\section{Identifying key actions to underpin pathways for change}

The pathways identified to move to a more sustainable 2030 are highly interconnected and realising a more sustainable 2030 will only occur through shifting away from Business-as-usual across the range of drivers identified here, as well drivers not considered here. For example, greater ocean literacy is needed to improve societal understanding of the ocean (Kelly et al. in review) and the role of food must be understood in the broader framing of the links between human and ocean health (Nash et al. in review-a). A total of 23 actions that underpin the pathways to a more sustainable 2030 were identified (Table S3). Some of these actions, 
such as the diversification of production and consumption, will be influenced by a range of drivers (Table 2, Figure S1). Others, for example awareness raising on the nutritional value of seafood, may be influenced by relatively few of the drivers identified. Some of the actions, such as policies to support domestic seafood sectors, will contribute to many of the pathways to a more sustainable future. Other actions, such as better use of waste and sustainable feed inputs, will contribute to one or two of our identified pathways. All actions are equally important, but identifying specific actions that contribute to the most pathways may be more impactful than implementing actions that contribute to achieving a single pathway. Prioritising actions that not only sustainably produce more seafood, but consider aspects of access and utilisation for all is essential. Prioritised actions are shown in Table 2 as examples of options to stimulate action in preparation for the UN Ocean Decade of Ocean Science for Sustainable Development to ensure that the goal of food for all is highlighted. Implementation of these actions will need to consider the effect of multiple, often competing drivers and the appropriateness of implementation at a range of scales, for example at local or global, in the near or distant future. The actions will need to be implemented by a variety of groups and result in a range of benefits.

Table 2 Priority actions, their drivers and the multiple pathways they can support, with one example of a specific action to implement the key action, including timeframe, who will undertake the action and who will benefit. More detailed information on all actions available in Table S3 and Figure S1.

\begin{tabular}{|c|c|c|c|c|c|c|}
\hline $\begin{array}{l}\text { Key } \\
\text { Actions }\end{array}$ & Driver & Pathways & $\begin{array}{l}\text { Specific } \\
\text { actions }\end{array}$ & $\begin{array}{l}\text { Time } \\
\text { frame to } \\
\text { start } \\
\text { action }\end{array}$ & $\begin{array}{l}\text { Who will } \\
\text { do } \\
\text { activity? }\end{array}$ & $\begin{array}{l}\text { Who will } \\
\text { benefit? }\end{array}$ \\
\hline $\begin{array}{l}\text { Diversification } \\
\text { of production } \\
\text { and } \\
\text { consumption }\end{array}$ & $\begin{array}{l}\text { Ecosystem } \\
\text { change } \\
\text { Influence of } \\
\text { corporations } \\
\text { Output and } \\
\text { efficiency } \\
\text { Consumer } \\
\text { demand } \\
\text { Nutrition } \\
\text { focus }\end{array}$ & $\begin{array}{l}\text { 1. Improve } \\
\text { seafood access, } \\
\text { availability \& } \\
\text { utilisation } 3 . \\
\text { Reduce } \\
\text { impacts from } \\
\text { production \& } \\
\text { consumption }\end{array}$ & $\begin{array}{l}\text { Collaborative } \\
\text { investment to } \\
\text { increase } \\
\text { diversity of } \\
\text { mariculture } \\
\text { species }\end{array}$ & Short-term & $\begin{array}{l}\text { Seafood } \\
\text { industry, } \\
\text { government }\end{array}$ & $\begin{array}{l}\text { Consumers, } \\
\text { industry, } \\
\text { society }\end{array}$ \\
\hline $\begin{array}{l}\text { Policies to } \\
\text { support } \\
\text { domestic } \\
\text { seafood sector }\end{array}$ & $\begin{array}{l}\text { Regulation of } \\
\text { oceans }\end{array}$ & $\begin{array}{l}\text { 1. Improve } \\
\text { seafood access, } \\
\text { availability\& } \\
\text { utilisation } 2 . \\
\text { Sustainable } \\
\text { management } \\
4 . \\
\text { Collaboration } \\
\text { \& cooperation } \\
\text { 5. Reduced } \\
\text { inequality }\end{array}$ & \multicolumn{2}{|c|}{$\begin{array}{l}\text { Policies/governandenmediate } \\
\text { frameworks } \\
\text { identifying } \\
\text { sustainable } \\
\text { pathways for } \\
\text { supporting } \\
\text { domestic } \\
\text { fisheries and } \\
\text { value chains } \\
\text { supplying local } \\
\text { markets }\end{array}$} & $\begin{array}{l}\text { Government, } \\
\text { private sector }\end{array}$ & $\begin{array}{l}\text { Domestic } \\
\text { seafood } \\
\text { industry, } \\
\text { consumers }\end{array}$ \\
\hline
\end{tabular}




\begin{tabular}{|c|c|c|c|c|c|c|}
\hline $\begin{array}{l}\text { Key } \\
\text { Actions }\end{array}$ & Driver & Pathways & $\begin{array}{l}\text { Specific } \\
\text { actions }\end{array}$ & $\begin{array}{l}\text { Time } \\
\text { frame to } \\
\text { start } \\
\text { action }\end{array}$ & $\begin{array}{l}\text { Who will } \\
\text { do } \\
\text { activity? }\end{array}$ & $\begin{array}{l}\text { Who will } \\
\text { benefit? }\end{array}$ \\
\hline $\begin{array}{l}\text { Implementation } \\
\text { ecosystem- } \\
\text { based } \\
\text { management } \\
(\mathrm{EBM})\end{array}$ & $\begin{array}{l}\text { Ecosystem } \\
\text { change } \\
\text { Regulation of } \\
\text { oceans }\end{array}$ & $\begin{array}{l}\text { 2. Sustainable } \\
\text { management } \\
\text { 3. Reduce } \\
\text { impacts from } \\
\text { production \& } \\
\text { consumption } \\
4 \text {. } \\
\text { Collaboration } \\
\& \text { cooperation }\end{array}$ & $\begin{array}{l}\text { Operationalise } \\
\text { EBM and } \\
\text { trade-off tools } \\
\text { at national } \\
\text { and regional } \\
\text { scales }\end{array}$ & Immediate & $\begin{array}{l}\text { Industry, } \\
\text { government, } \\
\text { research } \\
\text { community }\end{array}$ & $\begin{array}{l}\text { Industry, } \\
\text { consumers, } \\
\text { environment }\end{array}$ \\
\hline $\begin{array}{l}\text { Supply chain } \\
\text { transparency }\end{array}$ & $\begin{array}{l}\text { Influence of } \\
\text { corporations } \\
\text { Consumer } \\
\text { demand }\end{array}$ & $\begin{array}{l}\text { 2. Sustainable } \\
\text { management } 3 \\
\text { Reduce } \\
\text { impacts from } \\
\text { production \& } \\
\text { consumption } \\
4 \text {. } \\
\text { Collaboration } \\
\& \text { cooperation }\end{array}$ & $\begin{array}{l}\text { Wide imple- } \\
\text { mentation of } \\
\text { regulations } \\
\text { and technology } \\
\text { to ensure } \\
\text { supply chain } \\
\text { transparency }\end{array}$ & $\begin{array}{l}\text { Short - } \\
\text { medium }\end{array}$ & $\begin{array}{l}\text { Private sector, } \\
\text { NGOs, Joint } \\
\text { seafood indus- } \\
\text { try/government } \\
\text { initiatives }\end{array}$ & $\begin{array}{l}\text { Consumers, } \\
\text { governments } \\
\text { (through } \\
\text { reduced } \\
\text { enforcement } \\
\text { requirements), } \\
\text { environment }\end{array}$ \\
\hline $\begin{array}{l}\text { Cross-sectoral } \\
\text { spatial } \\
\text { planning }\end{array}$ & $\begin{array}{l}\text { Ecosystem } \\
\text { change } \\
\text { Regulation of } \\
\text { oceans }\end{array}$ & $\begin{array}{l}\text { 2. Sustainable } \\
\text { management } \\
\text { 4. } \\
\text { Collaboration } \\
\text { \& cooperation } \\
\text { 5. Reduced } \\
\text { inequality }\end{array}$ & $\begin{array}{l}\text { Implementation } \\
\text { of MSP } \\
\text { frameworks } \\
\text { with strategic } \\
\text { planning } \\
\text { across sectors }\end{array}$ & Immediate & $\begin{array}{l}\text { Managers, } \\
\text { supported by } \\
\text { research } \\
\text { community } \\
\text { and indigenous } \\
\text { leaders }\end{array}$ & $\begin{array}{l}\text { Environment, } \\
\text { seafood } \\
\text { industry, } \\
\text { community } \\
\text { (including } \\
\text { indigenous } \\
\text { groups) }\end{array}$ \\
\hline $\begin{array}{l}\text { Co- } \\
\text { management } \\
\text { marine } \\
\text { resources }\end{array}$ & $\begin{array}{l}\text { Regulation of } \\
\text { oceans }\end{array}$ & $\begin{array}{l}\text { 2. Sustainable } \\
\text { management } \\
\text { Collaboration } \\
\& \text { cooperation } \\
\text { 5. Reduced } \\
\text { inequality }\end{array}$ & $\begin{array}{l}\text { Build } \\
\text { relationships } \\
\text { between } \\
\text { resource-user } \\
\text { groups and } \\
\text { government } \\
\text { agency or } \\
\text { NGOs to share } \\
\text { management } \\
\text { responsibilities } \\
\text { and authority }\end{array}$ & Immediate & $\begin{array}{l}\text { Government, } \\
\text { NGOs, fishers }\end{array}$ & $\begin{array}{l}\text { Environment, } \\
\text { fishers, } \\
\text { community }\end{array}$ \\
\hline
\end{tabular}




\begin{tabular}{|c|c|c|c|c|c|c|}
\hline $\begin{array}{l}\text { Key } \\
\text { Actions }\end{array}$ & Driver & Pathways & $\begin{array}{l}\text { Specific } \\
\text { actions }\end{array}$ & $\begin{array}{l}\text { Time } \\
\text { frame to } \\
\text { start } \\
\text { action }\end{array}$ & $\begin{array}{l}\text { Who will } \\
\text { do } \\
\text { activity? }\end{array}$ & $\begin{array}{l}\text { Who will } \\
\text { benefit? }\end{array}$ \\
\hline $\begin{array}{l}\text { Inclusion small } \\
\text { scale and } \\
\text { non-market } \\
\text { values }\end{array}$ & $\begin{array}{l}\text { Influence of } \\
\text { corporations }\end{array}$ & $\begin{array}{l}4 . \\
\text { Collaboration } \\
\text { \& cooperation } \\
\text { 5. Reduced } \\
\text { inequality }\end{array}$ & $\begin{array}{l}\text { Establish } \\
\text { agreements } \\
\text { between small } \\
\text { and large } \\
\text { enterprise to } \\
\text { share } \\
\text { information, } \\
\text { provide } \\
\text { enterprise } \\
\text { opportunities } \\
\text { and ensure } \\
\text { access rights }\end{array}$ & Medium & Private sector & $\begin{array}{l}\text { Small- } \\
\text { enterprise, } \\
\text { community }\end{array}$ \\
\hline $\begin{array}{l}\text { Co-production } \\
\text { knowledge }\end{array}$ & $\begin{array}{l}\text { Ecosystem } \\
\text { change Output } \\
\text { and efficiency }\end{array}$ & $\begin{array}{l}4 . \\
\text { Collaboration } \\
\text { \& cooperation } \\
\text { 5. Reduced } \\
\text { inequality }\end{array}$ & $\begin{array}{l}\text { Targeted } \\
\text { engagement } \\
\text { with } \\
\text { managers, } \\
\text { fishers and } \\
\text { coastal } \\
\text { communities } \\
\text { around } \\
\text { strategies for } \\
\text { responding to } \\
\text { change }\end{array}$ & Immediate & $\begin{array}{l}\text { Government } \\
\text { and seafood } \\
\text { industry, } \\
\text { academia, } \\
\text { indigenous } \\
\text { communities }\end{array}$ & $\begin{array}{l}\text { local } \\
\text { communities } \\
\text { (including } \\
\text { indigenous) } \\
\text { and seafood } \\
\text { industry }\end{array}$ \\
\hline
\end{tabular}

\section{Conclusion}

This paper outlines both an anticipated, 'Business-as-usual', future scenario and five potential pathways to generate action to move toward a more sustainable 2030. The narrative approach used to stimulate thinking about potential futures highlight that we must prepare for an increasingly uncertain future in terms of our use of natural resources and ecosystems and ability to be both prepared and adaptable to provide a growing population with a nutritious and secure supply of seafood. While there is much to be concerned about, there are many positive actions already occurring. The extent to which we build on and implement these actions forms the main divide between our scenarios. For example, knowledge and technology are changing rapidly but their uptake and application differ within and between countries. In a more optimistic future, broader implementation of currently established or emerging technologies would be enabled as a result of better collaboration and cooperation. This collaboration would support the coproduction of knowledge, to improve food and nutrition outcomes, instead of a one directional transfer of technological information. Collaboration would also enable groups to improve and adapt their fishing and farming practices in a way that is most suitable to their specific needs.

Our scenarios explored the need for increasing seafood production to meet consumer demand, as well as meeting the needs of those who are food and nutrition insecure. Under a Business-as-usual scenario, access to seafood may be increasingly constrained by supply disruptions, however, many types of seafood will remain affordable to those able to pay for it. For less affluent consumers, access to good quality seafood will continue to be limited. Improving this situation will require identifying and prioritising actions to increase availability and accessibility of quality seafood, as well as maintaining access to the coast for those who rely on wild capture fisheries or small-scale mariculture for food. 
Sustainable and flexible fisheries management and integrated frameworks that cover all ocean users and recognise cultural values will be key to ensuring effective strategic planning across sectors. Wild systems will compete with mariculture production, and other sectors of the emerging 'blue economy' for access to near shore areas. The Business-as-usual scenario will see management struggling to meet multiple goals across environmental, economic and social priorities, and ongoing inequitable sharing of benefits. In a more sustainable future, where targets for oceans and food are aligned within policy and management, there is scope for inequality to be reduced and for the seafood harvested to make the maximum contribution to human nutrition and well-being with minimal impact.

\section{References}

Allison EH (2011) Aquaculture, fisheries, poverty and food security vol Working Paper 2011-65. WorldFish,

Allison EH et al. (2020) The Human Relationship with Our Ocean Planet

Alonso-Población E, Siar SV (2018) Women's participation and leadership in fisherfolk organizations and collective action in fisheries: a review of evidence on enablers, drivers and barriers. Rome, FAO.

Bai X et al. (2016) Plausible and desirable futures in the Anthropocene: A new research agenda Global Environmental Change 39:351-362

Barange M (2019) Global fishing sustainability challenges and successes. Paper presented at the International Symposium on Fisheries Sustainability, Rome, 12 December 2019

Bell JD et al. (2015) Diversifying the use of tuna to improve food security and public health in Pacific Island countries and territories Marine Policy 51:584-591

Belton B, Reardon T, Zilberman D (2020) Sustainable commoditization of seafood Nature Sustainability:1-8

Béné C, Barange M, Subasinghe R, Pinstrup-Andersen P, Merino G, Hemre G-I, Williams M (2015) Feeding 9 billion by 2050 - Putting fish back on the menu Food Security 7:1-14 doi:10.1007/s12571-015-0427-z

Bennett A, Patil P, Kleisner K, Rader D, JohnVirdin J, Basurto X (2018) Contribution of Fisheries to Food and Nutrition Security: Current Knowledge, Policy, and Research.

Bennett EM et al. (2016) Bright spots: seeds of a good Anthropocene Frontiers in Ecology and the Environment 14:441-448

Blanchard JL et al. (2017) Linked sustainability challenges and trade-offs among fisheries, aquaculture and agriculture Nature Ecology \& Evolution 1:1240

Bogard JR, Farmery A, Little D, Fulton EA, Cook M (2019a) Will fish be part of future healthy and sustainable diets? The Lancet Planetary Health 3:e159-e160

Bogard JR, Farmery AK, Baird DL, Hendrie GA, Zhou S (2019b) Linking production and consumption: The role for fish and seafood in a healthy and sustainable Australian diet Nutrients 11:1766

Borrini-Feyerabend G, Campese J (2017) Self-Strengthening ICCAs - Guidance on a process and resources for custodian indigenous peoples and local communities vol draft for use by GSI partners. The ICCA Consortium,

Buck BH, Troell MF, Krause G, Angel D, Grote B, Chopin T (2018) State of the art and challenges for offshore integrated multi-trophic aquaculture (IMTA) Frontiers in Marine Science 5:165

Butcher H, Burkhart S, Paul N, Tiitii U, Tamuera K, Eria T, Swanepoel L (2020) Role of Seaweed in Diets of Samoa and Kiribati: Exploring Key Motivators for Consumption Sustainability 12:7356

CAUL (2015) Indigenous Engagement and Participation Strategy. The Clean Air and Urban Landscapes Hub, National Environmental Science Programme, 
Chen X et al. (2017) A novel combined recirculating treatment system for intensive marine aquaculture Aquaculture research 48:5062-5071

Cisneros-Montemayor AM, Pauly D, Weatherdon LV, Ota Y (2016) A global estimate of seafood consumption by coastal indigenous peoples PLoS One 11:e0166681

Cohen P et al. (2019) Securing a just space for small-scale fisheries in the blue economy Frontiers in Marine Science 6:171

Cohen PJ, Foale SJ (2013) Sustaining small-scale fisheries with periodically harvested marine reserves Marine Policy 37:278-287

Costello C et al. (2020) The future of food from the sea Nature doi:10.1038/s41586-020-2616-y

Costello C et al. (2016) Global fishery prospects under contrasting management regimes Proceedings of the National Academy of Sciences 113:5125-5129 doi:10.1073/pnas.1520420113

Cottier-Cook E et al. (2016) Safeguarding the future of the global seaweed aquaculture industry United Nations University (INWEH) and Scottish Association for Marine Science Policy Brief:12

Crawford MA, Broadhurst CL (2012) The role of docosahexaenoic and the marine food web as determinants of evolution and hominid brain development: the challenge for human sustainability Nutrition and health 21:17-39

Dahlstrom MF, Ho SS (2012) Ethical considerations of using narrative to communicate science Science Communication 34:592-617

Dutra LX et al. (2019) Governance mapping: A framework for assessing the adaptive capacity of marine resource governance to environmental change Marine Policy

Eriksson $\mathrm{H}$ et al. (2016) An ecosystem approach to small-scale fisheries through participatory diagnosis in four tropical countries Global Environmental Change 36:56-66 doi:https://doi.org/10.1016/j.gloenvcha.2015.11.005

Eriksson H, Troell M, Brugere C, Chadag M, Phillips M, Andrew N (2018) Equitable mariculture: A diagnostic framework for equitable mariculture development in the Western Indian Ocean

Evans LS, Hicks CC, Fidelman P, Tobin RC, Perry AL (2013) Future Scenarios as a Research Tool: Investigating Climate Change Impacts, Adaptation Options and Outcomes for the Great Barrier Reef, Australia Human Ecology 41:841-857 doi:10.1007/s10745-013-9601-0

FAO (2009) How to Feed the World in 2050.

FAO (2015) Voluntary Guidelines for Securing Sustainable Small-Scale Fisheries in the Context of Food Security and Poverty Eradication. Food and Agriculture Organization of the United Nations, Rome

FAO (2018) The State of World Fisheries and Aquaculture 2018 - Meeting the sustainable development goals. Food and Agriculture Organization of the United Nations, Rome

FAO (2020a) How is COVID-19 affecting the fisheries and aquaculture food systems. Rome. doi:https://doi.org/10.4060/ca8637en

FAO (2020b) Nutrient content of fish powder from low value fish and fish byproducts. FAO. https://csirspace.foodresearchgh.site/handle/123456789/1135. Accessed 6 October 2020

Farmery A et al. (in review) Blind spots in the Blue Economy risk limiting contributions to food and nutrition One Earth

Farmery AK, Gardner C, Jennings S, Green BS, Watson RA (2017) Assessing the inclusion of seafood in the sustainable diet literature Fish and Fisheries 18:607-618 
Farrell P et al. (2020) COVID-19 and Pacific food system resilience: opportunities to build a robust response Food Security:1-9

Gaines SD et al. (2018) Improved fisheries management could offset many negative effects of climate change Science Advances 4:eaao1378 doi:10.1126/sciadv.aao1378

Gentry RR et al. (2017) Mapping the global potential for marine aquaculture Nature Ecology \& Evolution $1: 1317$

Gephart JA et al. (2020) Scenarios for global aquaculture and its role in human nutrition Reviews in Fisheries Science \& Aquaculture:1-17

Global Panel (2020) Future Food Systems: For people, our planet, and prosperity. Global Panel on Agriculture and Food Systems for Nutrition, London, UK

Godwin SE, Morrison RN, Knowles G, Cornish MC, Hayes D, Carson J (2020) Pilchard orthomyxovirus (POMV). II. Causative agent of salmon orthomyxoviral necrosis, a new disease of farmed Atlantic salmon Salmo salar. Diseases of Aquatic Organisms in press

Gokoglu N (2019) Innovations in Seafood Packaging Technologies: A Review Food Reviews International:1-27 doi:10.1080/87559129.2019.1649689

Golden C et al. (2016) Fall in fish catch threatens human health Nature 534:317-320

Groesbeck AS, Rowell K, Lepofsky D, Salomon AK (2014) Ancient clam gardens increased shellfish production: adaptive strategies from the past can inform food security today PloS one 9

Hambrey J (2017) The 2030 Agenda and the Sustainable Development Goals: The challenge for aquaculture development and management FAO Fisheries and Aquaculture Circular

Hayward C, Svane I, Lachimpadi S, Itoh N, Bott N, Nowak B (2011) Sea lice infections of wild fishes near ranched southern bluefin tuna (Thunnus maccoyii) in South Australia Aquaculture 320:178-182

Hicks CC et al. (2019) Harnessing global fisheries to tackle micronutrient deficiencies Nature 574:95-98

Hilborn R et al. (2020) Effective fisheries management instrumental in improving fish stock status Proceedings of the National Academy of Sciences

Hiriart-Bertrand L, Silva JA, Gelcich S (2020) Challenges and opportunities of implementing the marine and coastal areas for indigenous peoples policy in Chile Ocean \& Coastal Management 193:105233

HLPE (2014a) Food losses and waste in the context of sustainable food systems. A report by the High Level Panel of Experts on Food Security and Nutrition of the Committee on World Food Security. Rome

HLPE (2014b) Sustainable fisheries and aquaculture for food security and nutrition. A report by the High Level Panel of Experts on Food Security and Nutrition of the Committee on World Food Security, Rome 2014.

Hoegh-Guldberg O et al. (2019) The Ocean as a Solution to Climate Change: Five Opportunities for Action. World Resources Institute, Washington, DC

Hua K et al. (2019) The Future of Aquatic Protein: Implications for Protein Sources in Aquaculture Diets One Earth 1:316-329

Imagine a world (2020) Imagine a world without hunger, then make it happen with systems thinking. Feeding the world involves tackling all aspects of the food system (Editorial) Nature 577:293-294 doi:10.1038/d41586020-00086-5

IPBES (2019) Global assessment report on biodiversity and ecosystem services of the Intergovernmental Science-Policy Platform on Biodiversity and Ecosystem Services. . IPBES secretariat, , Bonn, Germany 
IPCC (2019) IPCC Special Report on Climate Change, Desertification, Land Degradation, Sustainable Land Management, Food Security, and Greenhouse gas fluxes in Terrestrial Ecosystems. Intergovernmental Panel on Climate Change, Geneva

Jackley J, Gardner L, Djunaedi AF, Salomon AK (2016) Ancient clam gardens, traditional management portfolios, and the resilience of coupled human-ocean systems Ecology and Society 21

Johnson DS, Acott TG, Stacey N, Urquhart J (2018) Social wellbeing and the values of small-scale fisheries. Springer,

Kelly R, K. et al. (in press) Connected to the oceans: supporting ocean literacy and public engagement Reviews in Fish Biology and Fisheries. DOI:10.1007/s11160-020-09616-w

Lowery B, Dagevos J, Chuenpagdee R, Vodden K (2020) Storytelling for sustainable development in rural communities: An alternative approach Sustain Dev

Mahon R, Fanning L (2019) Regional ocean governance: Polycentric arrangements and their role in global ocean governance Marine Policy 107:103590

Mangi SC, Dolder PJ, Catchpole TL, Rodmell D, de Rozarieux N (2015) Approaches to fully documented fisheries: practical issues and stakeholder perceptions Fish and Fisheries 16:426-452

Marean CW et al. (2007) Early human use of marine resources and pigment in South Africa during the Middle Pleistocene Nature 449:905 doi:10.1038/nature06204

https://www.nature.com/articles/nature06204\#supplementary-information

McClean N, Barclay K, Fabinyi M, Adhuri D, Sulu R, Indrabudi T (2019) Assessing tuna fisheries governance for community wellbeing: case studies from Indonesia and Solomon Islands. University of Technology Sydney, Sydney

Merrie A, Keys P, Metian M, Österblom H (2018) Radical ocean futures-scenario development using science fiction prototyping Futures 95:22-32

Moxness Reksten A et al. (2020) Sampling protocol for the determination of nutrients and contaminants in fish and other seafood - The EAF-Nansen Programme MethodsX 7:101063 doi:https://doi.org/10.1016/j.mex.2020.101063

Nash K et al. (in review-a) Oceans and society: feedbacks between ocean and human health Authorea. October 02, 2020. DOI: 10.22541/au.160166568.89566317

Nash KL, Alexander K, Melbourne-Thomas J, Novioaglio C, Sbrocchi C, Villanueva C, Pecl GT (in reviewb) Developing Achievable Alternate Futures for Key Challenges during the UN Decade of Ocean Science for Sustainable Development Authorea. October 02, 2020. DOI: 10.22541/au.160166561.14686672

Nature (2020) Sustainable solutions to end hunger. Nature. https://www.nature.com/collections/dhiggjeagd. Accessed 19 October 2020

Neudorf CM, Smith N, Lepofsky D, Toniello G, Lian OB (2017) Between a rock and a soft place: Using optical ages to date ancient clam gardens on the Pacific Northwest PloS one 12

Nippon Foundation (2017) Oceans and Sustainable Development Goals: Co-benefit, Climate Change and Social Equity. Vancouver

Norström AV et al. (2020) Principles for knowledge co-production in sustainability research Nature Sustainability doi:10.1038/s41893-019-0448-2

Olson R (2015) Houston, we have a narrative: why science needs story. University of Chicago Press,

Österblom H, Jouffray J-B, Folke C, Rockström J (2017) Emergence of a global science-business initiative for ocean stewardship Proceedings of the National Academy of Sciences 114:9038-9043 
Österblom H, Wabnitz CCC, Tladi D (2020) Towards Ocean Equity. World Resources Institute, Washington, $\mathrm{DC}$

Packer H, Swartz W, Ota Y, Bailey M (2019) Corporate social responsibility (CSR) practices of the largest seafood suppliers in the wild capture fisheries sector: From vision to action Sustainability 11:2254

Papargyropoulou E, Lozano R, Steinberger JK, Wright N, bin Ujang Z (2014) The food waste hierarchy as a framework for the management of food surplus and food waste Journal of Cleaner Production 76:106-115 doi:10.1016/j.jclepro.2014.04.020

Pecl GT et al. (in review) Transforming our oceans for the future we want Reviews in Fish Biology and Fisheries This issue

Porter ME, Kramer MR (2019) Creating Shared Value. In: Lenssen GG, Smith NC (eds) Managing Sustainable Business: An Executive Education Case and Textbook. Springer Netherlands, Dordrecht, pp 323-346. doi:10.1007/978-94-024-1144-7_16

Posner SM, Cvitanovic C (2019) Evaluating the impacts of boundary-spanning activities at the interface of environmental science and policy: A review of progress and future research needs Environmental science \& policy 92:141-151

Raudsepp-Hearne C et al. (2019) Seeds of good anthropocenes: developing sustainability scenarios for Northern Europe Sustainability Science doi:10.1007/s11625-019-00714-8

Rockström J, Sukhdev P (2019) How food connects all the SDGs. Stockholm Resilience Centre. https://www.stockholmresilience.org/research/research-news/2016-06-14-how-food-connects-all-thesdgs.html. Accessed 15/12/2019 2019

Rudolph TB, Ruckelshaus M, Swilling M, Allison EH, Österblom H, Gelcich S, Mbatha P (2020) A transition to sustainable ocean governance Nature communications 11:1-14

Sachs JD, Schmidt-Traub G, Mazzucato M, Messner D, Nakicenovic N, Rockström J (2019) Six Transformations to achieve the Sustainable Development Goals Nature Sustainability:1-10

Sale PF et al. (2014) Transforming management of tropical coastal seas to cope with challenges of the 21st century Marine Pollution Bulletin 85:8-23

Schubel JR, Thompson K (2019) Farming the Sea: The Only Way to Meet Humanity's Future Food Needs GeoHealth 3:238-244 doi:10.1029/2019gh000204

Singh GG et al. (2018) A rapid assessment of co-benefits and trade-offs among Sustainable Development Goals Marine Policy 93:223-231 doi:https://doi.org/10.1016/j.marpol.2017.05.030

Smith DC et al. (2017) Implementing marine ecosystem-based management: lessons from Australia Ices Journal of Marine Science 74:1990-2003 doi:10.1093/icesjms/fsx113

Stentiford GD et al. (2020) Sustainable aquaculture through the One Health lens Nature Food 1:468-474 doi:10.1038/s43016-020-0127-5

Stoll JS, Bailey M, Jonell M (2019) Alternative pathways to sustainable seafood Conservation Letters n/a:e12683 doi:10.1111/conl.12683

Swanepoel L, Tioti T, Eria T, Tamuera K, Tiitii U, Larson S, Paul N (2020) Supporting Women's Participation in Developing A Seaweed Supply Chain in Kiribati for Health and Nutrition Foods 9:382

Swedbio, ACIAR (2020) Enhancing livelihoods while governing marine resources in Pacific Island countries. WorldFIsh. https://worldfish.exposure.co/ingredients-for-success. Accessed 6 October 2020

Tacon AGJ, Hasan M, Metian M (2011) Demand and Supply of Feed Ingredients for Farmed Fish and Crustaceans. Rome, Italy 
Taylor MD et al. (2017) Fisheries enhancement and restoration in a changing world. Elsevier,

Taylor SFW, Roberts MJ, Milligan B, Ncwadi R (2019) Measurement and implications of marine food security in the Western Indian Ocean: an impending crisis? Food Security 11:1395-1415 doi:10.1007/s12571019-00971-6

Tezzo X, Bush SR, Oosterveer P, Belton B (2020) Food system perspective on fisheries and aquaculture development in Asia Agriculture and Human Values doi:10.1007/s10460-020-10037-5

Thilsted SH, Thorne-Lyman A, Webb P, Bogard JR, Subasinghe R, Phillips MJ, Allison EH (2016) Sustaining healthy diets: The role of capture fisheries and aquaculture for improving nutrition in the post-2015 era Food Policy:126-131

United Nations (2015) Transforming our world: the 2030 Agenda for Sustainable Development. United Nations Resolution A. RES/70/1. New York,

van Putten I, Koopman M, Fleming A, Hobday AJ, Knuckey I, Zhou S (2019) Fresh eyes on an old issue: Demand-side barriers to a discard problem Fisheries Research 209:14-23 doi:https://doi.org/10.1016/j.fishres.2018.09.007

Weirowski F, Hall SJ (2008) Public-private partnerships for fisheries and aquaculture: getting started. The WorldFish Center, Penang, Malaysia

Willett W et al. (2019) Food in the Anthropocene: the EAT-Lancet Commission on healthy diets from sustainable food systems The Lancet

World Bank (2013) Fish to 2030: Prospects for Fisheries and Aquaculture. World Bank Report Number 83177-GLB. Washington DC

Young MA (2017) Energy transitions and trade law: lessons from the reform of fisheries subsidies International Environmental Agreements: Politics, Law and Economics 17:371-390 doi:10.1007/s10784-017-9360-2

Zhou S et al. (2010) Ecosystem-based fisheries management requires a change to the selective fishing philosophy Proceedings of the National Academy of Sciences 107:9485-9489 doi:10.1073/pnas.0912771107 